\title{
The scope of expected nursing advice in primary health care from the patients' perspective: a qualitative study
}

Zakres oczekiwanych porad pielęgniarskich w podstawowej opiece zdrowotnej z perspektywy pacjentów: badania jakościowe

\section{Ewa Taranta1 ${ }^{\oplus}$, Ludmiła Marcinowicz ${ }^{2} \oplus$, Sławomir Terlikowski ${ }^{\circledR}$}

'Przychodnia Rodzinna "Fidos" B. Saczko i Wspólnicy sp.j. Białystok, ul. Siewna 2,
doktorantka na Wydziale Nauk o Zdrowiu Uniwersytetu Medycznego w Białymstoku
2Zakład Położnictwa, Ginekologii i Opieki Położniczo-Ginekologicznej,
Uniwersytet Medyczny w Białymstoku, 15-295 Białystok, ul. Szpitalna 37

CORRESPONDING AUTHOR/AUTOR DO KORESPONDENCJ:

Ewa Taranta

ul. Jarzębinowa 8 m 19, 15-793 Białystok e-mail: ewa.taranta@umb.edu.pl

STRESZCZENIE

Słowa kluczowe:

\section{ZAKRES OCZEKIWANYCH PORAD PIELĘGNIARSKICH W PODSTAWOWEJ OPIECE ZDROWOTNEJ Z PERSPEKTYWY}

\section{PACJENTÓW:BADANIA JAKOŚCIOWE}

Wprowadzenie. Uprawnienie pielęgniarek do wypisywania recept i udzielania porad pielęgniarskich w podstawowej opiece zdrowotnej może mieć wpływ na poprawę jakości tych świadczeń. W procesie zapewnienia jakości opieki zdrowotnej pożądanym elementem jej oceny jest perspektywa pacjenta z uwzględnieniem jego oczekiwań.

Cel pracy. Ustalenie zakresu oczekiwanych porad pielęgniarskich oraz poznanie opinii pacjentów dotyczących wypisywania recept przez pielęgniarki rodzinne.

Materiał i metodyka. Przeprowadzono badania jakościowe z wykorzystaniem półstrukturyzowanego wywiadu z 37 pacjentami, podopiecznymi ośmiu poradni podstawowej opieki zdrowotnej z województwa podlaskiego.

Wyniki. Zakres porad oczekiwanych od pielęgniarki rodzinnej dotyczy: postępowania w sytuacji wystąpienia problemu zdrowotnego, stylu życia i profilaktyki, zakresu opieki pielęgniarki rodzinnej i działania systemu ochrony zdrowia. Wypisywanie recept przez pielęgniarki rodzinne może usprawnić funkcjonowanie placówek podstawowej opieki zdrowotnej.

Wnioski. Postrzegane przez pacjentów porady pielęgniarskie są zgodne z kompetencjami pielęgniarki rodzinnej. Opinie na temat uprawnień pielęgniarki rodzinnej do wypisywania recept i samodzielnego ordynowania leków są zróżnicowane.

porada, pielęgniarka rodzinna, badania jakościowe

ABSTRACT

Key words:

\section{THE SCOPE OF EXPECTED NURSING ADVICE IN PRIMARY HEALTH CARE FROM THE PATIENTS' PERSPECTIVE:} A QUALITATIVE STUDY

Introduction. Nurses' entitlement to write prescriptions and to provide nursing advice in primary health care can improve the quality of these services. In the process of ensuring the quality of healthcare, the desirable element of its assessment is the patient's perspective, taking into account his expectations.

Aim. Determining the scope of expected nursing advice and learning the opinions of patients regarding the writing of prescriptions by family nurses.

Material and methods. A qualitative study was conducted using a semi-structured interview with 37 patients under the care of eight primary health care outpatient clinics from the Podlaskie Voivodeship.

Results. The scope of advice expected from a family nurse concerns: dealing with a health problem, lifestyle and prevention, the scope of family nurse care and the operation of the healthcare system. Writing prescriptions by family nurses can improve the functioning of primary health care.

Conclusions. Nursing advice perceived by patients is in line with the competences of the family nurse. Opinions on the entitlement of the family nurse to write prescriptions and prescribing medicines vary.

advice, family nurse, qualitative study 
Ewa Taranta, Ludmiła Marcinowicz, SławomirTerlikowski

\section{INTRODUCTION}

A nurse's and midwife's professional independence is achieved through constant broadening of their duties and professional skills. Authorizing the nurses on the $1^{\text {st }}$ of January 2016 to prescribe medication and giving out prescriptions and on the $1^{\text {st }}$ of January 2020 to give nursing advice at outpatient specialist clinics are examples of such actions being undertaken $[1,2]$. Amendment of the ordinance of the Minister of Health on services guaranteed in POZ as of August 1, 2020. it made it possible to provide nursing advice in this area of medical services [3]. It is anticipated that nursing advice will be crucial in making healthcare benefits more available in primary healthcare, especially in the countryside and among disabled people, where it is the family nurse, who has the most direct access to the patient. The range of nursing advice in the primary healthcare system would include: estimating the patient's condition, physical examination, writing out diagnostic referral forms, prescribing medication and giving out prescriptions. Depending on their personal professional qualifications and the patient's condition, the nurse would guide disease prevention and promote healthy lifestyle, decide on methods of wound treatment, and prescribe medical products [3]. Broadening the extent of the nurses' professional responsibilities may positively influence the evaluation of their services. Taking the patients' perspective and their expectations into account is necessary in the process of providing quality healthcare [4].

\section{AIM}

This research aimed to establish what extent of nursing advice the patients expect and what is their opinion on authorizing family nurses to prescribe medication.

\section{MATERIALS AND METHODS}

We have conducted qualitative research by means of interviewing. The research has been approved by the Bioethics Review Committee of the Medical University of Bialystok (Resolution no.: R-I-002/448/2016). 37 semi-structured interviews have been conducted with patients from general practice doctors' and family nurses' lists. The research took place in eight primary healthcare institutions in the Podlaskie Voivodeship. The interview guidebook comprised such questions as: What kind of ailment would you consult with a family nurse? What would you want to learn from a family nurse? Are you aware that family nurses are authorized to prescribe medication? What is your opinion on that? All the interviews were conducted by the same person - this paper's co-author (ET). The interviews were recorded onto a digital voice recorder and then transcribed in full. The data went through content analysis [5]. The interviews were conducted until theoretical saturation has been reached, that is until new data ceased to surface and new categories could not be established [6]. The research subjects were mostly women $(62.2 \%)$, people in long-term relationships (73\%), high school graduates (51.4\%) and currently retired or pension beneficiaries (64.9\%) (Tab. 1).
Tab. 1. The research subjects' profile $(n=37)$

\begin{tabular}{|c|c|c|}
\hline \multicolumn{2}{|c|}{ Variable } & \multirow{2}{*}{$\frac{\mathbf{n}(\%)}{14(37.8)}$} \\
\hline Cond & Men & \\
\hline entiuet & Women & $23(62.2)$ \\
\hline \multirow{2}{*}{ Age } & Average & 59.4 years old \\
\hline & Range & $30-88$ years old \\
\hline \multirow{4}{*}{ Education } & Elementary & $2(5.4)$ \\
\hline & Vocational & $8(21.6)$ \\
\hline & High school & $19(51.4)$ \\
\hline & University & $8(21.6)$ \\
\hline \multirow{3}{*}{ Marital status } & Married & $27(73)$ \\
\hline & Single & $4(10.8)$ \\
\hline & Widow/Widower & $6(16.2)$ \\
\hline \multirow{2}{*}{ Employment } & Active & $13(35.1)$ \\
\hline & Retired/Pensioner & $24(64.9)$ \\
\hline \multirow{2}{*}{ Health issue } & Present & $32(86.5)$ \\
\hline & None & $5(13.5)$ \\
\hline
\end{tabular}

\section{RESULTS}

Analysing the transcripts allowed to isolate three main categories of family nurse's advice, which are: 1 . information on how to proceed in case of an ailment, 2. information on healthy lifestyle and disease prevention, 3 information on family nursing and the healthcare system in general (Tab. 2).

Tab. 2. Patients' expectations towards the extent of nursing advice

\begin{tabular}{|c|c|c|}
\hline Kategorie & Sub-kategorie & Jednostki znaczeniowe \\
\hline \multirow[b]{2}{*}{$\begin{array}{l}\text { Advice on how } \\
\text { to proceed } \\
\text { in case of } \\
\text { a health issue } \\
\text { occurring }\end{array}$} & $\begin{array}{l}\text { Using } \\
\text { administered } \\
\text { medication }\end{array}$ & $\begin{array}{l}\text { How to take medication, what are the } \\
\text { contraindications and side effects. }\end{array}$ \\
\hline & $\begin{array}{c}\text { Methods of } \\
\text { easing symptoms }\end{array}$ & $\begin{array}{c}\text { How to stabilize a patient. } \\
\text { What diet to use in sickness. } \\
\text { Pain management. } \\
\text { Wound treatment. } \\
\text { Preventing bedsores. } \\
\text { Natural methods of easing symptoms of } \\
\text { a disease. }\end{array}$ \\
\hline \multirow{2}{*}{$\begin{array}{l}\text { Advice on } \\
\text { lifestyle } \\
\text { and disease } \\
\text { prevention }\end{array}$} & $\begin{array}{l}\text { Preventing } \\
\text { a health issue }\end{array}$ & $\begin{array}{l}\text { Advice on diet and physical activity. } \\
\text { Ways to improve health. } \\
\text { Information on prevention programs } \\
\text { and vaccines. }\end{array}$ \\
\hline & $\begin{array}{l}\text { Preventing } \\
\text { complications }\end{array}$ & $\begin{array}{c}\text { Range and frequency of routine check-ups. } \\
\text { Test results interpretation. }\end{array}$ \\
\hline \multirow{2}{*}{$\begin{array}{l}\text { Information } \\
\text { on a family } \\
\text { nurse's } \\
\text { capabilities } \\
\text { and the } \\
\text { healthcare } \\
\text { system }\end{array}$} & $\begin{array}{c}\text { Types of benefits } \\
\text { and care } \\
\text { continuity }\end{array}$ & $\begin{array}{c}\text { Range of a family nurse's capabilities. } \\
\text { Home visit availability. } \\
\text { Maintaining continuity of care. }\end{array}$ \\
\hline & $\begin{array}{l}\text { The rules of } \\
\text { receiving health } \\
\text { benefits outside } \\
\text { the primary } \\
\text { healthcare } \\
\text { system }\end{array}$ & $\begin{array}{c}\text { Acquiring medical equipment and wares. } \\
\text { Rules of using other providers' services. } \\
\text { Foreign healthcare }\end{array}$ \\
\hline
\end{tabular}




\section{Information on how to proceed in case of an ailment}

According to the interviewees, a family nurse should be able to advise on health issues generally considered to be less serious. The information given should be up to date with the latest medical knowledge.

"If the problem is less serious, then the nurse should be able to tell, what to do. They have to possess knowledge adequate to the given situation, so not to misinform the patient, not to harm them." (Subject 16)

Information on how to administer prescribed medication is another example of what the subjects have pointed out as expected from a family nurse.

"I'm often not sure how to use the medication - what time do I take it, do I take it before or after a meal and is there any interaction with other medication that I take, what should I not mix? The doctor will not always mention this if a patient doesn't ask." (Subject 15)

The advice on how to proceed in case of specific health issues may concern administering medication through injection. In treatment of diabetes, the family nurse teaches the patient how to make an injection by themselves.

"I do [administer] the insulin by myself because I'm diabetic. The nurse from the local facility taught me." (Subject 33)

The subjects expected the nurse to advise on how to ease the symptoms of an illness. Sometimes a nursing advice could substitute the necessity of visiting a doctor.

"Do I fight the fever, or do I let my body do the work? What do I do in case of a minor cold, when there's no need or no time to bother a doctor?" (Subject 3)

Some patients' experience indicates that a family nurse could advise them on matters concerning dietary measures.

"I'm on a diet ordered by a [family] nurse. I've got written instructions. I try to abide by it. Thanks to it, I don't need to take medication, I don't need insulin." (Subject 28)

From the patients' point of view, a family nurse is a better source of medical advice than a doctor and abiding by their instructions may give desired results.

"I had diabetic wounds and the nurse got me out of it, they're healed. Sometimes she would help me more than a doctor." (Subject 33)

The subjects expressed the desire to receive nursing advice on natural methods of reinforcing the organism and improving their overall condition.

"If I can't sleep, the family nurse always tells me, what to do. Maybe honey, maybe milk, or maybe a walk. Not just medication, but other methods, too. Not chemicals." (Subject 27)

\section{Lifestyle and disease prevention advice}

From the subjects' point of view, advising on lifestyle and disease prevention may be the right way to prevent health issues occurring. Dietary and physical activity advice on how to avoid excess weight is expected from a family nurse.

"How to prevent being overweight? What diet and what exercise shall I do to avoid gaining weight?" (Subject 15)
The subjects, who were unsure about the available prevention programs' effectiveness, expected the family nurse to be able to clarify the matter.

"Should I go to mammography or not? I heard it's not very safe. I've learned about cervical screening from [family] nurses, too." (Subject 2)

The disease prevention advice mentioned by the subjects also included the topic of vaccination.

"Vaccination, I'd like to know everything about vaccination. My head is spinning [...]. Let my family nurse tell me, how it is." (Subject 8)

Information on routine check-ups for people with diagnosed chronic diseases was also expected from family nurses. The questions concerned the frequency of such check-ups, how to avoid complications and how to assess, whether the treatment is effective.

"How often should I do check-ups and what kinds, and what's my blood pressure. I check my own blood pressure, because I take high blood pressure medication, and sometimes I don't know, if it's good or bad, is the medication working properly." (Subject 3)

The subjects expected the results of their tests to be interpreted. They assumed a family nurse possesses necessary knowledge to be able to do that.

"When I do blood tests, I should be able to ask a family nurse, whether they're good or bad. They know that, because they're educated, nowadays [...] and I don't have to go to a doctor." (Subject 4)

\section{Information on family nurses' care and the healthcare system}

The subjects expected the family nurse to be able to inform them on healthcare benefits and the continuity of care provided by family nurses. The lack of information on the matter was the reason, why some patients didn't know, in which cases they could use a family nurse's help.

"I would talk to a family nurse and ask when I can really use her assistance. I don't really know what their duties are and what can I expect from them." (Subject 12)

The subjects benefiting from domestic care expected information on who will provide them with continued care in case their family nurse was unavailable, e.g. on vacation.

"I'd like to know, when she takes a leave of absence, whether someone else would come and take care of my injuries." (Subject 31)

The subjects' statements indicate that they expect information on healthcare benefits outside of the primary healthcare system. Their concerns included acquiring medical equipment and other means necessary for taking care of patients at their homes.

"She [the family nurse] also got me a bed and an anti-bedsore mattress. I used her advice on where to ask, what organizations could help me get those." (Subject 27)

The subjects assume, that a family nurse should possess knowledge on medical insurance in other countries and be able to inform them on the matter.

"I'd ask about foreign healthcare. What do I do, before I travel? What insurance do I buy, or what to do, when I catch a cold or injure myself abroad?" (Subject 16) 
When asked to give their opinion on or to evaluate their experience with their family nurse, some subjects were surprised and lacked such knowledge.

"I must say I've never thought I could go to a family nurse. I know I could see a doctor, but a nurse - I didn't know that. If I go, I might as well see a doctor. I don't know what sort of problems I could consult with them. I can't say. I have never done that, so I don't know." (Subject 36)

\section{The subjects' experience and expectations regarding prescribing medication by general practice nurses}

The subjects knew about the nurses being authorized to prescribe medication mostly from the press and television. Their statements indicate they were not sure if GP nurses are also able to do that.

"I've heard on TV, that nurses will prescribe medication, but I thought it was restricted to hospital nurses, not all of them. Our [family nurses] don't prescribe medication, I think." (Subject 2)

The subjects opined that the ability to prescribe medication may improve a healthcare facility's effectiveness. The patients assume a family nurse has sufficient knowledge to be up to the task.

"It would improve the facility's operations. We wouldn't have to wait three days just to get a prescription. A family nurse could take care of it. Their knowledge is absolutely sufficient." (Subject 14)

The subjects, who were sceptical about the family nurses' ability to decide on prescribing medication by themselves, expressed their concern and the need to be careful in using this right.

"They [the nurses] have also graduated from adequate schools, but I'm not sure, if I want a nurse to be treating me [...]. How does a nurse know, how to diagnose a disease? If they do, they're a doctor, not a nurse." (Subject 2)

\section{DISCUSSION}

Counselling in a family nurse's work used to mostly concern disease prevention, education and promoting a healthy lifestyle [7]. The conducted research shows, that the expected range of nursing advice is much larger and concerns various aspects of life, which could improve or maintain one's health, as well. The research conducted by Wołosiewicz and her associates established, that $75 \%$ of the subjects expected the primary healthcare nurse to be able to advise them and answer their questions [8]. Alongside the questions of lifestyle and prevention, the research described here also includes patients expecting advice on avoiding gaining weight. Van Dillen and associates conducted research about the advice given by the Dutch primary healthcare nurses to patients struggling with being overweight and obese. The analysis of these consultations shows that the dietary and physical activity advice was incomplete and initiated mostly by the patients themselves and not the nurses [9]. The subjects of the research described here also expected advice on how to proceed after a health issue has occurred, information on a family nurse's capabilities and the healthcare system in general. A research regarding nursing advice indicated that the nurses' most common practice is nurse counselling (75.1\%) and health counselling (69.5\%), and the most common ways of conveying information are: individual conversation, motivation, explaining, instructing and advising [10]. The average time of educational counselling activity estimated in a research by the nurses is 15 to 20 minutes [11]. The distinction of nursing advice as a separately financed service may be an incentive for family nurses to make it a part of their daily practice and motivate them to take part in courses to upgrade their qualifications and update their knowledge on specific health issues. The current legislative state allows nurses to administer and prescribe medication and that task is a part of a nursing consultation $[1,3]$. The availability of this benefit would improve the overall availability of primary healthcare, as many patients point out the need to receive a prescription as a reason to visit a general practice doctor [12]. The research subjects also opined that the nurses' ability to prescribe medication could improve healthcare facilities' operations and shorten the time necessary to receive that benefit.

\section{CONCLUSIONS}

The range of known and expected nursing advice is wide and adequate to a family nurse's qualifications. A family nurse should be able to inform about medical insurance necessary to receive medical assistance when traveling abroad. It is expected that advice on healthy lifestyle and disease prevention will include information on dietary and physical activity measures for overweight patients. Thoughts on a nurse being authorized to prescribe and independently administer medication vary. It is assessed that such a benefit would improve the functioning of the primary healthcare system. The gathered results may be a starting point for further inquiry utilizing quantitative methods. 


\section{Zakres oczekiwanych porad pielęgniarskich w podstawowej opiece zdrowotnej z perspektywy pacjentów: badania jakościowe}

\section{WPROWADZENIE}

Samodzielność zawodowa pielęgniarki i położnej wyraża się w stałym poszerzaniu jej zadań $\mathrm{i}$ kompetencji zawodowych. Jednym $\mathrm{z}$ działań $\mathrm{w}$ tym zakresie jest wprowadzenie od 1 stycznia 2016r. uprawnienia do ordynowania leków i wypisywania recept, a od 1 stycznia 2020r. możliwość udzielania porad pielęgniarskich $\mathrm{w}$ ambulatoryjnej opiece specjalistycznej [1,2]. Nowelizacja roporządzenia Ministra Zdrowia dotycząca wykazu świadczeń gwarantowanych w POZ z dniem 1 sierpnia 2020r. wprowadziła możliwość realizacji porady pielęgniarskiej także w tym obszarze usług medycznych [3]. Zakłada się, że porada pielęgniarska w POZ będzie odgrywała duże znaczenie w dostępie do świadczeń zdrowotnych, zwłaszcza w środowisku wiejskim oraz wobec osób z niepełnosprawnością, gdzie to przede wszystkim pielęgniarka rodzinna dociera do pacjenta. Elementy porady pielęgniarskiej w POZ to ocena stanu zdrowia pacjenta, badanie fizykalne, skierowanie na badania diagnostyczne, ordynacja leków, wystawienie recepty. W zależności od posiadanych uprawnień zawodowych oraz stanu zdrowia pacjenta, pielęgniarka rodzinna będzie prowadzić profilaktykę chorób i promocję zdrowia, dobierać sposoby leczenia ran, wystawiać zlecenie na wyroby medyczne [3]. Poszerzanie zakresu kompetencji pielęgniarek rodzinnych może mieć wpływ na ocenę jakości świadczonych przez nie usług. W procesie zapewnienia jakości opieki zdrowotnej pożądanym elementem jej oceny jest perspektywa pacjenta $\mathrm{z}$ uwzględnieniem jego oczekiwań [4].

\section{CEL PRACY}

Celem badania było ustalenie zakresu oczekiwanych porad pielęgniarskich oraz poznanie opinii pacjentów dotyczących wypisywania recept przez pielęgniarki rodzinne.

\section{MATERIAŁ I METODYKA}

Zrealizowano badania jakościowe $\mathrm{z}$ wykorzystaniem techniki wywiadu. Na przeprowadzenie badania uzyskano zgodę Komisji Bioetycznej Uniwersytetu Medycznego w Białymstoku (Uchwała nr: R-I-002/448/2016). Półstrukturyzowane wywiady przeprowadzono z 37 pacjentami, zapisanymi na listę lekarza rodzinnego oraz na listę pielęgniarki rodzinnej. Badania zrealizowano w ośmiu poradniach medycyny rodzinnej w województwie podlaskim. Przewodnik wywiadu zawierał m.in. następujące pytania: Z jakim problemem zwróciłby się Pan/ zwróciłaby się Pani do pielęgniarki rodzinnej? Czego chciałby Pan/chciałaby Pani dowiedzieć się od pielęgniarki rodzinnej? Czy wie Pan/Pani, że pielęgniarki rodzinne mogą wystawiać recepty? Co Pan/Pani sądzi na ten temat? Wszystkie wywiady przeprowadzała ta sama osoba - współautorka pracy (ET). Wywiady zostały nagrane na dyktafon cyfrowy, a następnie w całości zapisane $\mathrm{w}$ formie transkryptów. Dane analizowano za pomocą techniki analizy treści [5]. Wywiady przeprowadzano do czasu nasycenia danych, to znaczy, gdy podczas kodowania nie pojawiały się nowe informacje i nie można było ustalić nowych kategorii [6]. Uczestnicy badania to w większości kobiety (62,2\%), osoby pozostające w związku $(73,0 \%)$, z wykształceniem średnim $(51,4 \%)$ oraz przebywające na emeryturze lub rencie $(64,9 \%)$ (tab.1).

Tab. 1. Charakterystyka uczestników badania $(\mathrm{n}=37)$

\begin{tabular}{|l|c|c|}
\hline \multirow{2}{*}{ Rłé́ } & Mężczyzna & $\mathbf{n}(\%)$ \\
\cline { 2 - 3 } & Kobieta & $14(37,8)$ \\
\hline \multirow{4}{*}{ Wiek } & Średnia wieku & $59(62,2)$ \\
\hline \multirow{4}{*}{ Wykształcenie } & Zakres wieku & $30-88$ lat \\
\hline \multirow{4}{*}{ Stan cywilny } & Podstawowe & $2(5,4)$ \\
\cline { 2 - 3 } & Zawodowe & $8(21,6)$ \\
\cline { 2 - 3 } & Średnie & $19(51,4)$ \\
\cline { 2 - 3 } & Wyżzze & $8(21,6)$ \\
\hline \multirow{3}{*}{ Aktywność zawodowa } & Mężatka/żonaty & $27(73)$ \\
\cline { 2 - 3 } & Wolna/wolny & $4(10,8)$ \\
\cline { 2 - 3 } & Wdowa/wdowiec & $6(16,2)$ \\
\hline \multirow{2}{*}{ Problem zdrowotny } & Osoba pracująca & $13(35,1)$ \\
\cline { 2 - 3 } & Emeryt/rencista & $24(64,9)$ \\
\cline { 2 - 3 } & Tak & $32(86,5)$ \\
\cline { 2 - 3 } & Nie & $5(13,5)$ \\
\hline
\end{tabular}

\section{WYNIKI BADAŃ}

Analiza treści transkryptów pozwoliła na wyodrębnienie trzech głównych kategorii tematycznych porad pielęgniarki rodzinnej, są to: 1) porady dotyczące postępowania w sytuacji wystąpienia problemu zdrowotnego; 2) porady na temat stylu życia i profilaktyki; 3 ) informacje dotyczące opieki pielęgniarki rodzinnej i działania systemu ochrony zdrowia (tab. 2). 
Tab. 2. Zakres udzielanych i oczekiwanych porad pielęgniarskich z perspektywy pacjentów

\begin{tabular}{|c|c|c|}
\hline Kategorie & Sub-kategorie & Jednostki znaczeniowe \\
\hline \multirow[b]{2}{*}{$\begin{array}{l}\text { Porady } \\
\text { dotyczące } \\
\text { postępowania } \\
\text { w sytuacji } \\
\text { wystąpienia } \\
\text { problemu } \\
\text { zdrowotnego }\end{array}$} & $\begin{array}{c}\text { Stosowanie } \\
\text { zaordynowanych } \\
\text { leków }\end{array}$ & $\begin{array}{l}\text { Sposób przyjmowania leków. } \\
\text { Interakcje i działania uboczne leków. }\end{array}$ \\
\hline & $\begin{array}{l}\text { Metody } \\
\text { łagodzenia } \\
\text { objawów } \\
\text { chorobowych }\end{array}$ & $\begin{array}{l}\text { Normalizacja parametrów życiowych. } \\
\text { Stosowanie diety w chorobie. } \\
\text { Łagodzenie bólu. } \\
\text { Leczenie ran. } \\
\text { Profilaktyka odleżyn. } \\
\text { Naturalne sposoby łagodzenia } \\
\text { objawów chorobowych. }\end{array}$ \\
\hline \multirow{2}{*}{$\begin{array}{l}\text { Porady na } \\
\text { temat stylu } \\
\text { życia } \\
\text { i profilaktyki }\end{array}$} & $\begin{array}{l}\text { Zapobieganie } \\
\text { wystąpieniu } \\
\text { problemów } \\
\text { zdrowotnych }\end{array}$ & $\begin{array}{l}\text { Porady nt. diety i aktywności fizycznej. } \\
\text { Sposoby wzmacniania zdrowia. } \\
\text { Informacje o programach profilaktycznych } \\
\text { i szczepieniach ochronnych. }\end{array}$ \\
\hline & $\begin{array}{l}\text { Zapobieganie } \\
\text { wystapieniu } \\
\text { powikłań }\end{array}$ & $\begin{array}{c}\text { Zakres i częstotliwość wykonywania badań } \\
\text { kontrolnych. } \\
\text { Interpretacja wyników badań. }\end{array}$ \\
\hline \multirow{2}{*}{$\begin{array}{l}\text { Informacje } \\
\text { dotyczące } \\
\text { opieki } \\
\text { pielęgniarki } \\
\text { rodzinnej } \\
\text { i działania } \\
\text { systemu } \\
\text { ochrony } \\
\text { zdrowia }\end{array}$} & $\begin{array}{c}\text { Rodzaje } \\
\text { świadczeń } \\
\text { i ciągłość opieki }\end{array}$ & $\begin{array}{l}\text { Zakres zadań pielęgniarki rodzinnej. } \\
\text { Terminy wizyt domowych. } \\
\text { Ciągłość opieki. }\end{array}$ \\
\hline & $\begin{array}{c}\text { Zasady udzielania } \\
\text { świadczeń poza } \\
\text { POZ }\end{array}$ & $\begin{array}{l}\text { Pozyskanie sprzętu i wyrobów medycznych. } \\
\text { Warunki korzystania z usług innych } \\
\text { świadczeniodawców. } \\
\text { Pomoc medyczna za granicą. }\end{array}$ \\
\hline
\end{tabular}

\section{Porady na temat postępowania w sytuacji wystąpienia problemu zdrowotnego}

Pielęgniarka rodzinna według uczestników badania, powinna udzielać porad w przypadku, gdy w ich ocenie problem zdrowotny nie jest zbyt poważny. Porady powinny być zgodne $\mathrm{z}$ aktualną wiedzą medyczną.

„Jeżeli ten problem jest troszeczkę mniej poważny, wtedy pielęgniarka rodzinna powinna udzielić porady co robić. Musi posiadać téz wiedzę medyczna adekwatna do danej sytuacji, żeby tego pacjenta nie wprowadzić $w$ błąd i nie zaszkodzić mu." (Uczestnik 16)

Uzyskanie informacji o prawidłowym stosowaniu zaordynowanych leków, to kolejne oczekiwanie skierowane przez uczestników badania do pielęgniarki rodzinnej.

„Często mam kłopot z tym jak stosować leki, o których godzinach można, przed jedzeniem czy po, i czy sa interakcje z innymi lekami, które biore, czego nie łaczyć. Lekarz nie zawsze powie o tym, bo nie zawsze się o to pyta." (Uczestnik 15)

Porady i informacje o sposobach postępowania w określonym stanie chorobowym dotyczyć mogą przyjmowania leków w postaci iniekcji. W przypadku leczenia cukrzycy, pielęgniarka rodzinna uczy pacjenta wykonania tych iniekcji samodzielnie.

„Insuline sam sobie robię, [przyjmuje] bo cukrzycę mam. Tu z mojej przychodni, moja pielegniarka rodzinna mnie nauczyła." (Uczestnik 33)

Uczestnicy badania oczekiwali od pielęgniarki rodzinnej porad na temat metod łagodzenia objawów chorobowych. Porada pielęgniarska mogłaby w niektórych przypadkach zastąpić konieczność odbycia wizyty lekarskiej.

„Czy zbijać goraczkę jak jest, czy dać organizmowi samemu walczyć? I co robić przy takich lekkich przeziębieniach, żeby nie iść od razu do lekarza, bo często nie ma potrzeby i czasu na to." (Uczestnik 3)

Doświadczenia niektórych uczestników badania pozwalają przypuszczać, że pielęgniarka rodzinna może udzielać im porad w zakresie leczenia dietetycznego.

„Diete stosuję, od pielegniarki [rodzinnej] taka kartkę $z$ dietą dostałem. Staram się stosować tą dietę. Dzięki temu nie trzeba brać leków, insuliny nie muszę brać." (Uczestnik 28)

Z perspektywy pacjentów, pielęgniarka rodzinna w udzielaniu porad dotyczących leczenia ran, jest lepszym doradcą niż lekarz i dzięki zastosowaniu się do jej zaleceń można uzyskać oczekiwany efekt leczenia.

„Ja miałem rany cukrzycowe i pielegniarka rodzinna mnie wyciagnęta $z$ tego, zagoiły się rany. Ona czasami więcej mi doradzi jak lekarz." (Uczestnik 33)

Uczestnicy badania wyrażali chęć skorzystania z porad pielęgniarki rodzinnej w zakresie stosowania naturalnych metod wspomagających organizm w radzeniu ze złym samopoczuciem.

„Jak źle sypiam, to pielegniarka rodzinna mi podpowiada zawsze co zrobić. Może miód, może mleko, a może spacer. Nie tylko leki, ale też inne metody, bez chemii." (Uczestnik 27)

\section{Porady na temat stylu życia i profilaktyki}

Z perspektywy uczestników badania, udzielanie porad dotyczących stylu życia i profilaktyki może być sposobem na zapobieganie wystąpieniu problemów zdrowotnych. Od pielęgniarki rodzinnej oczekiwano porad dotyczących diety i aktywności fizycznej zapobiegających wystąpieniu nadwagi.

„Jaka można zastosować profilaktykę nadwagi, jaka dietę zastosować, jakie ćwiczenia wykonywać żeby tej nadwagi nie było." (Uczestnik 15)

Uczestnicy badania, którzy mieli wątpliwości co do zasadności korzystania $\mathrm{z}$ dostępnych programów profilaktycznych uważali, że pielęgniarka rodzinna jest osobą, która te wątpliwości wyjaśni.

„Czy na mammografię iść czy nie, bo styszałam, że to nie jest za bardzo bezpieczne. O cytologii też od pielegniarek [rodzinnych] się dowiedziałam." (Uczestnik 2)

Wśród porad profilaktycznych udzielanych przez pielęgniarkę rodzinną uczestnicy badania oczekiwali tych, które dotyczą szczepień ochronnych.

„O szczepieniach, koniecznie o szczepieniach bym chciała się dowiedzieć wszystkiego. Mam mętlikw głowie kompletny [...]. To niech mi moja pielegniarka rodzinna powie, jak ma być." (Uczestnik 8)

Od pielęgniarki rodzinnej oczekiwano informacji na temat zakresu badań kontrolnych, jakie powinni wykonać pacjenci ze zdiagnozowanymi już chorobami przewlekłymi. Chodziło miedzy innymi o częstotliwość ich wykonania, co mogłoby być sposobem na zapobieganie powikłaniom tych chorób oraz elementem oceny skuteczności leczenia.

„Czy badania często trzeba robić i jakie, i ile ma wynosić ciśnienie. Mierzę sobie sam bo leki biore na nadciśnienie i czasem nie wiem czy dobre czy nie, czy te leki działaja tak jak trzeba." (Uczestnik 3) 
Uczestnicy badania oczekiwali interpretacji wyników wykonanych badań laboratoryjnych, uznając, że pielęgniarka rodzinna posiada stosowną wiedzę w tym zakresie.

"Jak wyniki robię $z$ krwi, to też pielegniarkę rodzinna można zapytać czy dobre, one też wiedza bo wykształcone sa teraz [...] i nie musze iść do lekarza." (Uczestnik 4)

\section{Informacje dotyczące opieki pielęgniarki rodzinnej i działania systemu ochrony zdrowia}

Uczestnicy badania oczekiwali od pielęgniarki rodzinnej informacji dotyczących rodzaju świadczeń i ciągłości opieki realizowanej przez pielęgniarkę rodzinną. Brak informacji o zakresie zadań pielęgniarki rodzinnej był powodem, dla którego niektórzy pacjenci nie wiedzieli w jakich sytuacjach mogą z jej pomocy skorzystać.

„Porozmawiałabym $z$ pielegniarka rodzinna i zapytałabym w jakiej sytuacji faktycznie można się do niej zwrócić. Bo nie bardzo wiem jakie sa jej obowiazki i z czym mogę do niej przyjść." (Uczestnik 12)

Osoby, objęte opieką pielęgniarki rodzinnej w domu, oczekiwały od niej informacji dotyczącej zapewnienia kontynuacji tej opieki w sytuacji, w której pielęgniarka rodzinna nie będzie mogła jej realizować np. $z$ powodu urlopu wypoczynkowego.

„Chciałabym wiedzieć, czy jak ona pójdzie na urlop to ktoś do mnie przyjdzie i zajmie się tymi ranami." (Uczestnik 31)

Z wypowiedzi uczestników badania wynika, że od pielęgniarki rodzinnej oczekiwano informacji na temat zasad udzielania świadczeń poza systemem POZ. Chodziło między innymi o możliwości pozyskania sprzętu medycznego i innych środków niezbędnych do opieki nad pacjentami w domu.

„Jeszcze mi załatwiła [pielęgniarka rodzinna] łóżko i materac przeciwodleżynowy. Skorzystałam $z$ jej porady gdzie się udać, przez jakie organizacje można to uzyskać." (Uczestnik 27)

Według osób badanych pielęgniarka rodzinna powinna mieć wiedzę na temat zasad ubezpieczenia zdrowotnego obowiązujących w innych krajach i udzielić pacjentom informacji w tym zakresie.

„Pytania, jeżeli chodzi o ochrone zdrowia za granica. Co trzeba zrobić i załatwić przed wyjazdem. Jakie wykupić ubezpieczenie, co powinienem zrobić jak się przeziębię tam, czy jak się skaleczę." (Uczestnik 16)

Niektórzy uczestnicy badania, poproszeni o wyrażenie opinii na temat porad pielęgniarki rodzinnej, wyrażali zdziwienie i brak wiedzy w tym zakresie.

„Powiem szczerze, że o tym nie myślałem, że moge iść do pielegniarki rodzinnej. Do lekarza to tak, ale do pielegniarki, nie wiedziatem o tym. Jak do pielegniarki, to lepiej chyba do lekarza. Nie wiem w jakiej sprawie moge się do niej zglosić. Trudno mi powiedzieć, nie korzystatem to nie wiem." (Uczestnik 36)

\section{Doświadczenia i oczekiwania uczestników badania związane z ordynowaniem leków i wypisywaniem recept przez pielęgniarki rodzinne}

Pacjenci biorący udział w badaniu wiedzę na temat uprawnień pielęgniarek do wypisywania recept uzyskiwali głównie z prasy i telewizji. Z ich wypowiedzi wynika, że nie mieli pewności czy pielęgniarki rodzinne też mają takie uprawnienia.

„Coś w telewizji styszałam, że pieleggniarki będa wypisywać recepty, ale to może te, które w szpitalu pracuja, bo nie wszystkie chyba. Nasze [pielegniarki rodzinne] chyba nie wypisują." (Uczestnik 2)

W opinii osób badanych możliwość wystawiania recept przez pielęgniarki rodzinne może usprawnić funkcjonowanie poradni. Pacjenci uznali, że wiedza pielęgniarki rodzinnej jest wystarczająca do realizacji tego zadania.

„To usprawni ogólnie funkcjonowanie przychodni. Żeby nie czekać trzy dni na wizytę po to tylko żeby wypisać lek. Można byłoby to załatwić z pielegniarka rodzinna. Jej wiedza wystarczy do tego w zupetności." (Uczestnik 14)

Uczestnicy badania, którzy wyrażali sceptycyzm co do samodzielnego wypisywania recept przez pielęgniarki rodzinne, sygnalizowali swe obawy i ostrożność w korzystaniu $\mathrm{z}$ tego uprawnienia.

„One [pielęgniarki] też przecież mają szkoły odpowiednie skończone, ale ja nie wiem czy chciałabym żeby pielegniarka mnie leczyła [...]. Skąd pielęgniarka może wiedzieć jaka to choroba, wtedy lekarzem byłaby, a nie pielegniarka." (Uczestnik 2)

\section{DYSKUSJA}

Poradnictwo w pracy pielęgniarki rodzinnej wiązało się dotychczas przede wszystkim z profilaktyką, edukacją zdrowotną i promocją zdrowia [7]. Z przeprowadzonych badań wynika, że z perspektywy pacjentów, zakres oczekiwanych porad pielęgniarskich jest znacznie szerszy i dotyczy różnych aspektów życia, które mogą mieć wpływ na zachowanie lub poprawę zdrowia. W badaniu przeprowadzonym przez Wołosewicz i wsp. ustalono, że $75 \%$ respondentów oczekiwało od pielęgniarki POZ udzielania porad i odpowiedzi na zadawane przez pacjenta pytania [8]. W badaniach własnych, wśród porad na temat stylu życia i profilaktyki pacjenci oczekiwali od pielęgniarki rodzinnej, m.in. porad zapobiegających wystąpieniu nadwagi. Van Dillen i wsp. przeprowadzili badania na temat porad udzielanych przez holenderskie pielęgniarki pracujące w POZ pacjentom z nadwagą i otyłością. Analiza przebiegu tych konsultacji pokazuje, że porady na temat odżywiania i aktywności fizycznej były fragmentaryczne, inicjowane częściej przez pacjentów, a nie pielęgniarki [9]. Pacjenci w prezentowanych badaniach własnych oczekiwali także porad dotyczących postępowania w sytuacji wystąpienia problemu zdrowotnego, informacji na temat zadań realizowanych przez pielęgniarki rodzinne i działania systemu ochrony zdrowia. Jedno $\mathrm{z}$ badań dotyczące udzielania porad pielęgniarskich wykazało, że najczęstszymi działaniami pielęgniarek w tym zakresie jest pro- 
wadzenie poradnictwa pielęgniarskiego $(75,1 \%)$ i zdrowotnego (69,5\%), a najczęściej stosowanymi formami przekazywania informacji są: rozmowy indywidualne, motywowanie, wyjaśnianie, instruowanie, doradzanie. [10]. Czas realizacji działań edukacyjnych związanych z poradnictwem, który określiły w jednym z badań pielęgniarki, wynosi od 15 do 20 minut [11]. Wyodrębnienie porady pielęgniarskiej jako osobno finansowanego produktu, może zachęcić pielęgniarki rodzinne do wprowadzenia tego zadania do codzienej praktyki, a także zmotywować je do uczestnictwa w szkoleniach podnoszących ich kwalifikacje i aktualizujących wiedzę na określone tematy związane ze zdrowiem. Aktualny stan prawny, uprawnia pielęgniarki polskie do ordynowania leków i wypisywania recept, a zadanie to jest jednym $\mathrm{z}$ elementów wchodzącym w skład porady pielęgniarskiej [1,3]. Ponieważ wśród powodów zgłaszania się do lekarza rodzinnego pacjenci często wskazują uzyskanie recepty, wprowadzenie tego rodzaju świadczenia może mieć wpływ na poprawę dostępności do POZ [12]. W opinii uczestników przeprowadzonego badania, możliwość wypisywania recept przez pielęgniarki rodzinne może także usprawnić funkcjonowanie przychodni i skrócić czas oczekiwania na uzyskanie tego zakresu świadczeń.

\section{WNIOSKI}

Zakres postrzeganych i oczekiwanych porad pielęgniarskich jest szeroki i zgodny z kompetencjami pielęgniarki rodzinnej. Pielęgniarka rodzinna powinna udzielać informacji o warunkach ubezpieczenia zdrowotnego uprawniającego do uzyskania pomocy medycznej podczas wyjazdu za granicę. Oczekuje się, że porady na temat stylu życia i profilaktyki zawierać będą miedzy innymi informacje dotyczące diety i aktywności fizycznej w zapobieganiu nadwadze. Opinie na temat uprawnień pielęgniarki rodzinnej do wypisywania recept i samodzielnego ordynowania leków są zróżnicowane. Uważa się, że wprowadzenie tego rodzaju świadczenia usprawni funkcjonowanie POZ. Uzyskane wyniki mogą stanowić wstęp do dalszych badań z zastosowaniem metod ilościowych.

\section{ORCID}

Ewa Taranta (iD) https://orcid.org/0000-0001-9929-4771

Ludmiła Marcinowicz (D) https://orcid.org/0000-0003-0614-1093

Sławomir Terlikowski (iD https://orcid.org/0000-0002-5091-026X

\section{REFERENCES/PIŚMIENNICTWO}

1. Ustawa z dnia 15 lipca 2011r. o zawodach pielęgniarki i położnej (Dz. U. z 2011r., poz.1039 ze zm.).

2. Rozporządzenie Ministra Zdrowia z dnia 23 września 2019r. zmieniające rozporządzenie w sprawie świadczeń gwarantowanych z zakresu ambulatoryjnej opieki specjalistycznej (Dz. U. z 2019r., poz.1864).

3. Rozporządzenie Ministra Zdrowia z dnia 8 lipca 2020r. zmieniające roporządzenie w sprawie świadczeń gwarantowanych z zakresu podstawowej opieki zdrowotnej (Dz. U. z 2020r., poz. 1255).

4. Marcinowicz L, Gugnowski Z, Strumiło J, i wsp. Czy pacjenci chcą oceniać jakość opieki zdrowotnej? Krótki sondaż wśród pacjentów. Family Medicine and Primary Care Review, 2015; 17 (1): 28-32.

5. Rapley T. Analiza konwersacji, dyskursu i dokumentów. Warszawa: Wydawnictwo Naukowe PWN; 2012.

6. Strauss A, Corbin J. Basics of qualitative research. Techniques and procedures for developing grounded theory. London, New Delhi: Sage Publications, Thousand Oaks; 1998.

7. Borowiak E, Kilańska D, Kunikowska B, Wielemborek-Musiał K. Promocja zdrowia i profilaktyka w praktyce pielegniarki P0Z. [w:] Pielęgniarstwo w podstawowej opiece zdrowotnej (red.) Kilańska D. Lublin: Wydawnictwo Makmed; 2008; tom I: 146-157.

8. Wołosewicz I, Kupcewicz E, Szypulska A, i wsp. Oczekiwania pacjentów wobec lekarza i pielęgniarki w podstawowej opiece zdrowotnej. [w:] Przedsiębiorczość i Zarządzanie. Wybrane problemy zarzadzania w pielęgniarstwie. Pielęgniarstwo bez granic (red) Majchrzak-Kłokocka E, Seliga R. Wydawnictwo SAN. 2013; XIV cz. 10 (2): 293-322.

9. van Dillen SME, Noordman J, van Dulmen S, Hiddink GJ. Examining the content of weight, nutrition and physical activity advices provided by Dutch practice nurses in primary care: analysis of videotaped consultations. European Journal of Clinical Nutrition. 2014; 68: 50-56.

10. Paszek T, Sienkiewicz Z, Wrońska I. Zastosowanie poradnictwa w działalności pielęgniarki. W: Rola zespołu terapeutycznego w interdyscyplinarnej opiece nad pacjentem. (Red) Krajewska-Kułak E, Szczepański M, Łukaszuk C. i wsp. Białystok; 2007: 319-326.

11. Pabiś M, Ślusarska B, Jarosz MJ i wsp. Kompetencje pielęgniarek w zakresie edukacji zdrowotnej w polskim systemie opieki medycznej. Pielęgniarstwo XXI Wieku. 2010; 3-4: 32-33.

12. Plentara R, Knyszyńska A, Bażydło M, i wsp. Satysfakcja pacjentów podstawowej opieki zdrowotnej z opieki medycznej i psychospołecznej. Pomeranian Journal of Life Science. 2015; 61 (3): 335-340.

Manuscript received/Praca zgłoszona do czasopisma: 29.05.2020

Manuscript accepted/Praca zaakceptowana do druku: 10.07.2020

Translation/Tłumaczenie: Agnieszka Wąsowska tłumaczenia, lokalizacja, komunikacja. 02-587 Warszawa, ul. Wiktorska 31/64 http://wasowska.net 